\title{
Past Behaviour, Conscientiousness Personality, and Attitude Toward Engagement in Workplace Affair
}

\author{
Muhammad Irfan Syaebani ${ }^{1}$, Alma Madina ${ }^{1}$, Melia Retno Astrini ${ }^{2}$ \\ 1. Faculty of Economics and Business, Universitas Indonesia, Jl. Prof. DR. Sumitro Djojohadikusumo, Kukusan, Kecamatan Beji, Kota Depok, Jawa \\ Barat 16424, Indonesia \\ 2. Tilburg School of Economics and Management, 5037 AB Tilburg, Netherlands
}

\begin{tabular}{|c|c|}
\hline ARTICLE INFO & A B S T R A C T \\
\hline $\begin{array}{l}\text { Keywords: } \\
\text { Workplace romance, } \\
\text { Workplace affair, } \\
\text { Attitude, } \\
\text { Past behaviour, } \\
\text { Conscientiousness } \\
\\
\text { Kata Kunci: } \\
\text { romansa di tempat kerja, } \\
\text { perselingkuhan di tempat kerja, } \\
\text { Sikap, } \\
\text { Perilaku masa lalu, } \\
\text { Kesadaran }\end{array}$ & $\begin{array}{l}\text { The phenomenon of workplace romance is an integral part of } \\
\text { organisational dynamics. Workplace romance might result in both } \\
\text { positive and negative effect. The negative side of workplace romance } \\
\text { bears the phenomenon of workplace affair, in which workers engage } \\
\text { in extra-marital relations with each other. This research aims to test } \\
\text { whether past behaviour, conscientiousness personality, which a part } \\
\text { of big five model personality traits and attitude have an impact on } \\
\text { the likelihood of employee's engagement in the workplace affair. As } \\
\text { many as } 250 \text { workers in Greater Jakarta participated in the survey with } \\
\text { minimum tenure six months as criteria of sampling. The analysis of } \\
\text { data is performed using structural equation modelling (SEM) process. } \\
\text { The result indicates that workers who have workplace romance } \\
\text { engagement in their past behaviour would affect the attitude of } \\
\text { perceiving workplace romance. The attitude itself plays as a mediator } \\
\text { between past behaviour and the engagement of workplace affair. At the } \\
\text { same time, personality determinant does not give any significant effect } \\
\text { on attitude and engagement in workplace affair. To mitigate the issue } \\
\text { of workplace affair, the organisation needs to perform background } \\
\text { checking prior accepting the employees since the past behaviour of } \\
\text { engagement in workplace romance is the reliable indicator of future } \\
\text { likelihood in workplace affair engagement. While the previous research } \\
\text { studies about the effect of workplace romance, this study emphasize } \\
\text { deeper into the findings from the workplace affair perspectives, which } \\
\text { is the negative effect of workplace romance. }\end{array}$ \\
\hline
\end{tabular}

\section{SARI PATI}

Fenomena romansa di tempat kerja adalah bagian integral dari dinamika organisasi. Romansa di tempat kerja dapat menghasilkan efek positif dan negatif. Sisi negatif dari romansa di tempat kerja adalah fenomena perselingkuhan di tempat kerja, di mana pekerja terlibat dalam hubungan di luar nikah satu sama lain. Penelitian ini bertujuan untuk menguji apakah perilaku masa lalu, kepribadian conscientiousness, yang merupakan bagian dari big five model personality traits dan sikap memiliki dampak pada kemungkinan keterlibatan karyawan dalam 
perselingkuhan di tempat kerja. Sebanyak 250 pekerja di Jabodetabek berpartisipasi dalam survei dengan masa kerja minimum enam bulan sebagai kriteria pengambilan sampel. Analisis data dilakukan dengan menggunakan proses pemodelan persamaan struktural (SEM). Hasilnya menunjukkan bahwa pekerja yang memiliki hubungan asmara di tempat kerja dalam perilaku masa lalu mereka akan mempengaruhi sikap terkait romansa di tempat kerja. Sikap itu sendiri berperan sebagai mediator antara perilaku masa lalu dan keterlibatan dalam perselingkuhan di tempat kerja. Pada saat yang sama, kepribadian conscientiousness tidak memberikan pengaruh signifikan pada sikap terkait romansa di tempat kerja dan keterlibatan dalam perselingkuhan di tempat kerja. Untuk mengatasi masalah perselingkuhan di tempat kerja, organisasi perlu melakukan pemeriksaan latar belakang sebelum menerima karyawan karena pengalaman masa lalu terkait keterlibatan dalam romansa di tempat kerja adalah indikator yang andal dari kemungkinan di masa depan untuk pekerja terlibat dalam perselingkuhan yang merupakan sisi negatif dari romansa di tempat kerja. Penelitian sebelumnya membahas efek dari romansa di tempat kerja, sedangkan penelitian ini lebih terfokus melihat dari sisi perselingkuhan di tempat kerja, yang merupakan efek negative dari romansa di tempat kerja.

\section{INTRODUCTION}

According to Shuck, Owen, Manthos, Quirk, \& Rhoades (2016), romance and work are two essential pillars of memorable life experiences. Moreover, Rabin-Margalioth (2006) in Shuck, Owen, Manthos, Quirk, \& Rhoades (2016) stated that many people spend most of their time to work; thus, it makes workplace romance becomes an unavoidable phenomenon, and sometimes it plays as a way for workers to find their soulmate.

However, workplace romance can transform into a complicated thing with various manifestations and motives behind it (Shuck, Owen, Manthos, Quirk, \& Rhoades, 2016). According to Quinn (1977), Foley and Powell (1999), and Pierce (1998) in Ariani, Ebrahimi, \& Saeedi (2011), workplace romance is a consensual relationship between two parties who work in the similar organisation, and it may involve physical attraction. The keyword of workplace romance is the existence of the mutualism of both parties to form a relationship. Workplace romance has several indicators such as involving emotional and physical attractiveness, intention to share, caring and helping and often include sexual behaviour like kissing, hugging or even sexual intercourse (Ariani, Ebrahimi, \& Saeedi, 2011).

Moreover, Wheatcroft (2016) admitted that many workers find their future spouse through a professional process rather than through other ways, such as from online dating or family referral. It is not surprising since many people spend most of their time to work. Many workers, who find their spouse because of romance in the workplace, experience long last marriage; a survey of CareerBuilder supports this. The survey concluded that in the US, almost $40 \%$ of workers have workplace romance experiences, and a third of them end in matrimony (BBC, 2017). In Germany, the percentage is higher rather than in the US, where $60 \%$ of workers have workplace romance experiences according to a survey conducted by kalaydo.de (BBC, 2017).

Refer to the explanation above, workplace romance is considered as something tolerable and can be accommodated by the organisation. If romance goes wrong, the organisation can intervene by imposing 
both strict and lenient policies (Karl \& Sutton, 2000). However, there is another phenomenon related to workplace romance, and it is called a workplace affair. Workplace affair happens when two parties engage in the romantic relationship, but one or both of the parties is already engaged in a legal relationship such as marriage. Workplace affair is perceived as the dark side of workplace romance. It is illegal and unethical (Abzug, 2016).

According to a survey conducted by CareerBuilder, in the US at least $20 \%$ of total workers who involved in workplace romance engaged in an illegitimate relationship, because one of the parties has been committed into marriage (Pizam, 2016). Moreover, SHRM also admitted that almost 1 of 6 workplace romance could be classified as a workplace affair because one of the party or even worse, both parties, have engaged in the legal relationship. Another fact revealed that more than $40 \%$ of executives confessed they ever engaged in workplace affair in the condition when one of the parties is already married (The Economist , 2005). Another survey conducted in the US showed almost half of married-men and forth of married-women engaged in extra-marital affair at least once during their lifetime (Jahan, Chowdhury, Rahman, Khair \& Huq, 2017).

If workplace romance may result in either a positive or negative impact, workplace affair only breeds a negative effect on the organisation. The indicators include decreasing respect of the people who engaged in the affair, causing excessive drama if the legal partner found out the affair and filing a complaint to the organisation, legal dispute, increasing absenteeism rate, affecting productivity, higher turnover, harmful media exposure and even it can affect the sales level (Career Intelligence, 2018). One example of the adverse effect of workplace affair is experienced by IBM when Robert Moffat, senior vice president, leaking the company secret to Danielle Chiesi whom accused by a federal attorney have an illegal affair with Robert. Another example happened in US red cross when president Mark W.
Everson is impeached because of engagement in workplace affair with his subordinate (Wall Street Journal, 2007).

The description above indicates company must manage the issue of romance in the workplace in order to mitigate the negative impact of it or at least to take precaution action by analysing the likelihood of employee's engagement in the workplace romance. Research of Doll and Rosopa (2015) to 148 full-time workers in educational institution found out that personal characteristic or personality has a significant effect on the intention of worker engaging in romance in the workplace. This personality element consists of attitude towards workplace romance, past behaviour concerning the experience of workplace romance, and conscientiousness, an indicator of Five-Factor Model personality inventory. The research concluded that a positive attitude towards workplace romance and past behaviour is proven affecting workplace romance likelihood engagement. Conscientiousness personality also affects attitude towards workplace romance and intention to engage in a workplace romance.

According to the explanation and to follow up the research of Doll \& Rosopa (2015), this study aims to extend the research of workplace romance which elaborates the illegitimate aspect of workplace romance or simply called workplace affair. Previous research has stated various antecedents of the reason behind people engagement in a workplace romance, such as personality factor and previous experience. This study tries to elaborate on whether those antecedents play a significant role in predicting the likelihood of employee's engagement in workplace affair, an illegitimate form of workplace romance.

While previous research of Doll \& Rosopa (2015) studied about the workplace romance, this research aims to extend the other perspective of the workplace romance, in which, seeing from the negative or illegitimate side of workplace romance. As workplace affair is practically happened in 
various way, this research proposed several implications to the organization or company on how to face this phenomenon to reduce the unimportant mess that can affect the employee's productivity. This study can be also used as an ethical factor for organization in considering the promotional agenda for middle and top management by conducting the background checking prior to the promotion.

\section{LITERATURE REVIEW}

\section{Workplace Romance}

Today, many women actively involved in a professional job; thus, it makes the interaction between male and female at work is more intense rather than decades ago. The intensity of teamwork is increasing together with more extended working hour, and it is considered as factors contributed to the occurrence of workplace romance since it makes the probability of employee's romance in every organisation rises (Shuck, Owen, Manthos, Quirk, \& Rhoades, 2016). Moreover, Houston (2007) in Kolesnikova \& Analoui (2012) admitted that in modern corporate society, the office is often associated as a single bar. It implies that office is the perfect place for a person to show his/her real colour and the best version of them (both in physical appearance and intellectual capacity) and also a place to find the right partner since many people spend many of their time working; thus, it allows them to know each other intensively (Kolesnikova \& Analoui, 2012).

Workplace romance can be defined as an intense emotional relationship between two employees and expressing that feeling through the date or intimate contact (Mainiero, 1989; Quinn, 1977). Workplace romance can be explained as a mutual relationship between two parties at work, and it may involve sexual encounter or physical intimate in it (Biggs, Matthewman, \& Fultz, 2012 ). Workplace romance requires a certain level of emotional intimacy between employees involved in it.

Following to Karl \& Sutton (2000), workplace romance can happen between co-workers or lateral relationship and between superordinate and subordinate or hierarchical relationship. Workplace romance between co-workers (lateral) is different from hierarchical workplace romance in term of the consequence it brings. Workplace romance can happen between employees who work in a similar department or different department. Moreover, according to Pierce \& Aguinis (2001), workplace romance can be classified based on the motive behind it. Usually, the reasons of workplace romance consist of (a) sincere motive where the basis of the relationship is because of mutual love; (b) fling motive where relationship emphasises heavily into fun, and (c) utilitarian motive where the relationship is aimed to gain personal benefit. A couple with sincere motive usually wants long term relationship and higher commitment, while a couple with fling motive often utilises the relationship to fulfil their short-term desire and do not have any intention to form more serious commitment. A couple with utilitarian motivation formed a relationship to secure their position in the office or as a way to get promotion since they perceived their partner has a power to do so (Pierce \& Aguinis, 2001). Previous research of Anderson \& Fisher (1991); Brown \& Allgeier (1996); Dillard \& Broetzmann (1980); and Quinn (1977) (in Pierce \& Aguinis, 2001) also tried to make a taxonomy of workplace romance based on the motive behind it. It consists of; (a) love motive where parties involved in the romance sincerely seek for future partner, (b) ego motive where the parties involved in the relationship just want to find for adventure, happiness, sexual experiences, or egoistic satisfaction, and (c) jobrelated motive where the relationship is utilised to find career progress, power, and career security and the relationship is formed as a return for financial incentives, less workload, or more extended work break and days off.

The newest research done by Pierce, Karl, \& Brey (2012), it shows that workplace romance could be classified based on the motive of every party involved in it. It will create more types of workplace romance since it considered both parties' reason to 
engage. It consists of (a) Love-love motive where both of parties involved in a relationship because of compassionate love, (b) Love/ego-love/ego motive where both parties might conceive that their relationship involves compassionate love in one side but also egoistic motive in the other hand such as seek for sexual experience, (c) Ego-ego motive where both of the parties just find satisfaction to their selfish needs such as sexual desire or a love adventure, (d) Job-job motive where both of the parties in the relationship utilise the romance for their career purpose such as to seek promotion, and (e) Ego-job motive where one party in the relationship uses the romance to fulfil his/her egoistic desire and another party uses the romance for career purposes. This type of motive usually exists when the relationship happens between superordinate and subordinate or hierarchical workplace romance (Pierce, Karl, \& Brey, 2012). According to Banker, Kaestle, \& Allen (2010); workplace romance can be divided based on the level of intimacy between two parties who involved in it. It is a romantic partnership, sexual partnership, combination partnership, and not-yetromantic partnership. The romantic partnership involves strong emotional attractiveness, and it has a strong commitment between two parties even though it may not contain a sexual encounter. In this relationship, sexual and physical contact is less important. The couple usually emphasises emotional intimacy. This relationship can be seen through several actions such as dating and romantic activities. This relationship also often associates with positive emotional feeling, mutual support, affectionate behaviour, and deep compassionate feeling.

The sexual partnership involves minimal emotional intimacy and emphasises on an intensive physical and sexual encounter. Sometimes, this relationship is qualified as a one-night-stand relationship because it does not require long term commitment. Sexual partnership implies a limited relationship, and it does not cover the things that not explicitly stated before the relationship begins. Usually, the person involved in this relationship needs a sexual or physical encounter, and they do not seek for compassionate love and further commitment to form a more serious relationship. Combination partnership requires a combination of a sexual and romantic relationship between parties. It associated with both emotional commitment and sexual or physical encounter. It has intense romance but also involves physical desire. This relationship is defined as true, real, and healthy romance. The relation which is formed from the combination partnership usually will lead to more serious commitment, and it has a future orientation.

The last one is a not-yet-romantic partnership. This relationship can be said as an open relationship since it opens many possibilities in the future. The relationship may end as a romantic partnership, sexual partnership or combination partnership. Language connotation which associated with this relationship, including hang out, more in-depth conversation, more than just friend relation, flirting, and casual dating. This relationship does not have any status yet, and it leads to a decision making the process for further relation. A not-yet-romantic partnership can be considered as the time frame when people involved in the relationship need time to decide whether they have mutual attractiveness and go to further direction. It is the time when both parties try to know each other before the "real" relationship begins. This relationship usually begins before the romantic, sexual, or combination relationship started.

Workplace romance is a phenomenon that perceived as usual, and many organisations did not have strict regulation to thwart it as long it does not bear negative consequences to the organisation, and the relationship is not the illegitimate one. However, it is reported that many people who engaged in the workplace romance which characterised as illegitimate because one of the parties already committed in legal relationship such as marriage; thus, the romance becomes illegitimate and unethical. Such a relationship is 
called a workplace affair, and it is the dark side of workplace romance (Fan \& Lui, 2004).

\section{Workplace Affair}

Workplace affair is considered as deviant behaviour and is an unacceptable form of workplace romance. Workplace affair is also seen as a problem and is accused as the main reason behind a divorce (Jahan, Chowdhury, Rahman, Khair, \& Huq 2017). According to Douglas LaBier, Ph.D., a psychologist and director of Center for Progressive Development in Washington, DC in Psychology Today (2010), based on his research affair can be divided into several categories. There are; It's-Only-Lust affair I'll-Show-You affair, Just-In-The-Head affair, All-InThe-Family affair, It's-Not-Really-An-Affair affair, dan Mind-Body affair.

"It's-Only-Lust" affair is the most common form of the affair, and it is related to sex. This affair can be intense, but usually, it ends in a short period. The main motive behind this affair purely to satisfy sexual desire because the parties feel the affair as a form of sexual liberation. Both parties do not have any intention to leave their legal partner and form a new relationship. However, they may feel emotional attachment besides sexual satisfaction from their affair partner. This affair will end when both parties do not feel any desire anymore because of the core basis of this affair, just sexual interest (LaBier, 2010). "I'll-Show-You" or Revenge/Resentment Affair, this affair happens when one party is in the resentment condition to his/her legal partner and want to take revenge by committing into an illegitimate relationship. This affair is often triggered because people feel neglected, have deep sadness, and being ignored. This affair usually happens because people think it is the only way to feel empowered and cure to every pain. The main problem which leads to this type of affair, usually the existence of hatred toward his/her legal partner as a result of negligent. When an individual involves in an affair, he/she usually uses this affair to gain the power of bargaining (LaBier, 2010).
"Just-In-The-Head" or Emotional Affair, emphasised that affair is not always related to a sexual encounter. Many affairs start from the deep connection between co-workers because they work together in a similar project, for example. By the time being, both parties feel engaged with one and another, even though it does not include any physical contact. Many extramarital affairs happen in the level of emotional connection only. This case occurs because both parties are attracted not only by physical appearance but also because of similarity in a world perspective, spirituality, and hobby. The couple continually shares everything almost every time, and even though this affair does not involve any sexual activities, but it does not mean sexual tension is unavailable between them. Both of them share every detail thing, including a sensitive issue, and they feel strongly connected. Usually, this affair starts with small talk and spending time together, in the end, the emotional connection is growing between them, and the just-in-headaffair is created. People who involve in this type of affair does not have any intention to leave his/her legal partner; thus, they perceived this affair just as deep friendship or platonic love. It involves secure and deep emotional attachment but not a sexual encounter.

"All-In-The-Family" Affair is a type of affair between people who belong to one family. Sometimes this type of affair is considered as unusual, but the likelihood of occurrence is still probable - for example, an affair between husband and sister in law or any other combinations. The worst effect of this affair is the dysfunctionality of the family when it is revealed. Hatred and anger may follow afterwards (LaBier, 2010). "It's-NotReally-An-Affair" or Imaginary Affair happens when one party believes that he/she engaged in a serious relationship, but another party denies this relationship. In this affair, one party waits to have a real relationship and willing to leave his/her legal partner while another party believe the relationship does not have any prospect in the future; thus, does not have any intention to process the affair further. 
In the record, usually, many women are trapped in this relationship. They believe that her partner has the willingness to create a serious relation, not just a casual affair. However, many men never fulfil the hope of his partner and still maintain his marriage and refuse to turn his affair into a legal relationship (LaBier, 2010).

The last one is the "Mind-Body" affair. This type is considered as a fatal affair since the effect of this affair usually leads to divorce. In this affair, both parties are involved physically and mentally. It means this affair is similar with usual love romance where the couple has an attachment emotionally, sexually, intellectually, and spiritually. The relationship is powerful and gives a mutual benefit. However, one or both parties have engaged in legal marriage with another partner. This affair is the real threat to the marriage. Many couples try to end this affair, but many of them failed because they feel their partner is the perfect match. A previous marriage is considered as a mistake. This affair, in one side, gives a positive effect to the couple involved in the affair if it ends in good relationship such as marriage. However, this affair always gives negative consequences to the family since many of this affair led to divorce and re-marriage, especially when kids are involved in the conflict and must bear the impact of a broken family (LaBier, 2010).

A qualitative study of Jahan, Chowdhury, Rahman, Khair, \& Huq (2017) explained various reasons for workplace affair engagement. The study indicated that many people who engage in workplace affair usually married in the age of early 20 . It is the stage when the emotional stability of a person is not yet balance or condition of compos mentis is not yet achieved.

Sexual dissatisfaction also reported as the antecedent of a workplace affair. Low self-control, financial problem, and an adventurous attitude are other factors contributed to the workplace affair. According to a survey conducted by CareerBuilder, in United Stated as many as $20 \%$ of workplace romance can be classified as workplace affair since one or both parties engaged in it already have legal commitment or marriage with another partner (Pizam, 2016).

Society of Human Resource Management also reported based on their survey that 1 of 6 or $16 \%$ of romance in the workplace can be categorised as workplace affair because one or both the parties involved have engaged in marriage and have significant other in their life. It is believed that workplace affair only breeds a negative outcome for the organisation. It affects absenteeism rate, productivity, excessive drama, working climate and increase litigation risk. The adverse effect of lousy media publication is also one of the adverse effects of workplace affair (Career Intelligence, 2018).

From the above explanation, it concludes that it is imperative to prevent workplace affair . The organisation needs to formulate a policy which can thwart the phenomenon from manifestation. Many scholars argue that antecedent of workplace affair can come from the surrounding environment but also personality disposition. Doll \& Rosopa (2015) said that romance in the workplace is triggered by employees' attitude, past behaviour, and conscientiousness personality.

\section{Attitude}

Following the theory of reasoned action formulated by Ajzen \& Fishbein (1980), a person's behaviour is determined by his/her behaviour intention. Behaviour intention itself is affected by a person's attitude towards the particular behaviour and also his/her perception of how other people think and expect about the particular behaviour or called a subjective norm.

Attitude is an evaluative statement whether positive or negative about particular object, person, or event. Attitude also reflects the affective side of a person or how he/she feels about something. A person's attitude towards particular behaviour can be indicated by his/her general feeling about the 
consequences of the behaviour, whether it gives advantage or disadvantage result (Foong \& Khoo, 2015).

According to psychological theory, attitude is a psychological construction, mental and emotional entity that characterises a person. The property of attitude is complex, and it originates from life experience a person is exposed. Attitude is mental stated which associated with specific values and embedded through responsive expression towards a person, place, object, or event and in the end, it affects individual action. In simple terminology, attitude is defined as an evaluative statement towards something, and it is a reflection of a person's emotion.

Theory of Planned Behavior of Ajzen (1985, in Doll \& Rosopa, 2015) further explained that besides social norm and personal control, attitude is a strong predictor of someone's behaviour. For example, when an employee has a good attitude about workplace romance and the organisational norm allows the attitude and the employee have control over the behaviour usually the likelihood of employee to engage in workplace romance is higher. It usually means a person's attitude will manifest in the behaviour. Pierce (1998) illustrated the association between attitude and engagement of workplace romance. In the study, Pierce (1998) argued that attitude toward workplace romance has a strong correlation with engagement in a workplace romance, for example, if an employee thinks about workplace romance positively, the tendency of workplace romance engagement rises.

Based on the results of previous studies done by Doll \& Rosopa (2015), which shows a positive relationship between attitude towards workplace romance and willingness to engage in workplace romance. So, it can be said that, if the employees have a positive attitude towards workplace romance, then the employees will too, act according to their intentions, by tending to get engaged in the workplace romance. Through previous research, it can be believed, employees with positive attitude towards workplace affair (a more specific form of the workplace romance), then their tendency to get engaged in a workplace affair is also positive. This follow the hypothesis 2 (H2) in the research which states: Attitude of employees in Jabodetabek towards workplace affair has positive effect to their intention to engage in a workplace affair.

\section{Past Behaviour}

Attitude is proven as a strong predictor of behaviour, and attitude itself is believed shaped through the life experience of a person. It implies that past behaviour or experience will determine the attitude of a person towards something, including workplace romance. If the employee has previous experience in the past concerning romance in the workplace, in the future, it will affect the attitude of employee positively.

In the last decades, several studies have indicated that past behaviour or experience will determine the likelihood of a person to replicate or to avoid the similar behaviour in the future (Trafimow \& Borrie, 1999). Following self-perception theory which cited by Doll \& Rosopa (2015), it explains that when an individual creates a confident attitude, it will be based on experience or past behaviour. If the past behaviour gives pleasant experience, $a$ person most likely will have a positive attitude in the future and vice versa, negative attitude appears if past behaviour gives unpleasant behaviour. The experience may be experienced by a person directly through his/her behaviour or perhaps through other's behaviour, and the experience is shaped because of observation.

As an illustration, perhaps an employee does not have any judgment towards workplace romance. When the employee engaged in the workplace romance, which means already have had experience about it, the employee will likely to behave in the future concerning romance in the workplace based on his/her previous experience. 
If the experience is unpleasant, the attitude may be negative and vice versa. The attitude will determine future behaviour. Thus, engagement in workplace romance will likely occur because of a person's past behaviour and attitude. Moreover, Ouellette \& Wood (1998) confirmed in their research that past behaviour would predict future behaviour. Past behaviour of workplace romance will predict workplace romance behaviour in the future. The behaviour manifestation will stronger if the attitude towards particular behaviour is positive, which implies that attitude is the mediator between past behaviour and future behaviour (Doll \& Rosopa, 2015).

Based on previous research conducted by Doll \& Rosopa (2015), the result states that there is a positive relationship between past behavior in workplace romance with his intention to be involved in the workplace romance. Thus, from the results of these studies, it can also be hypothesed that past behavioror prior engagement in a workplace romance for employees in Jabodetabek gives positive effect on the desire to engage in a workplace affair. Thus, the researches create the hypothesis 1 (H1) which states: Past behavior or prior engagement in the workplace romance at Jabodetabek has a positive effect on the intention to engage in workplace affair. According to Doll \& Rosopa (2015), it states that there is a positive correlation between past behavior in the workplace romance with its attitudes towards workplace romance. Based on this research, it can be also believed that if the employees have been involved in the workplace romance in the past, then their attitudes towards workplace affair will also be positive. This leads to the hypothesis $4(\mathrm{H} 4)$ which states: Past behavior or prior engagement in a workplace romance for employees at Jabodetabek has a positive effect on its attitude towards the workplace affair.

\section{Conscientiousness}

Past behaviour and attitude are proven as a strong predictor of behaviour. However, many scholars argue that personality disposition also plays essential roles in determining a person's behaviour. Concerning workplace romance, in particular, conscientiousness personality, which is one dimension of Big Five Personality, will affect the likelihood of people creating intimacy with a co-worker. Many studies concerning personality traits explain the effect of personal disposition into behaviour in various situations (Ali, 2018). Big Five is a theory about personality which emerged in the $20^{\text {th }}$ century, and it is considered as the widely accepted and used by many scholars and practitioners when evaluating a person's personality.

Moreover, Big Five Model has been implemented for years, and it is admitted being able to provide a framework for an organisation to fully comprehend a person's personality in the broader spectrum (Arora \& Rangnekar, 2016). The theory consists of five personality factors, and each factor has six facets; thus, the Big Five Model will create thirty elements of personality. The theory is formulated by a researcher named Lewis Goldberg, who explained the theory in his study about the analysis factor of personality traits, and it was named Big Five.

By the time being, in the late 1980 and early 1990, many psychologists who have focused on personality chooses Five-Factor Model formulated by Costa and McCrae rather than model formulated by Goldberg. The new model is considered more solid and valid because it can be applied to many cultural contexts. Big Five consists of five dimensions; (1) neuroticism or emotional stability, (2) extraversion which related to the assertiveness and energetic trait, (3) openness which related to autonomy, imaginary, and independency in thinking, (4) agreeableness or cooperativeness, and (5) conscientiousness or dependability and order trait.

Conscientiousness is a dimension which explains the ability of a person to organise things, persistency level, self-control, and motivation to achieve the goal (Costa \& McCrae, 1990). Conscientiousness 
also reflects of how far an individual makes self-judgement and achievement orientation. It characterises through obedience to rule and regulation, hard-working, ambitiousness, wellorganised, and responsibility. Effective planning and efficient time management will allow people to have more free time; thus, it will ease the pressure, lowering stress level, and minimise conflict (Ali, 2018). A person with a high level of conscientiousness tends to be more organised, trustworthy, dependable, and high achiever. It makes them easier to complete the tasks, create a positive mood, and boost self-esteem. On the contrary, a person with a low level of conscientiousness tends to be more spontaneous and less organised. There are six facets of conscientiousness; there are; (1) competence, it relates with the ability to do something, (2) order, it connects with the ability to organise, (3) dutifulness, it correlates with dependability, (4) achievement-striving, (5) selfdiscipline, and (6) deliberation or consideration before action (Costa \& McCrae, 1990). Currently, many recruiters utilise Big Five Model for a personality inventory tool when recruiting new candidates (Pulakos, 2005 in Doll \& Rosopa, 2015).

According to Doll \& Rosopa (2015), previous studies have investigated the probable relation between personality and workplace romance. Moreover, Doll \& Rosopa (2015) specifically identify a high level of conscientiousness as the personality determinant in shaping the attitude of a person toward workplace romance, and in the end, the attitude will become the strong predictor of behaviour. Conscientiousness trait is perceived as a strong association with the quality of the relationship that a person has, commitment, and closeness (Doll \& Rosopa, 2015). Following Doll \& Rosopa (2015), conscientiousness is the only factor in Big Five which determines the relationship passion or attractiveness physically and sexually both from men and women, thus in this study conscientiousness as a personality trait is believed can predict the likelihood of people to engage in workplace romance or workplace affair. Based on research conducted by Schmidt \&
Shackelford (2008) to 13,000 respondents in 46 countries, stated that conscientiousness has a negative relationship with extra-pair mating or affair. In North America, it is also found that conscientiousness also has a negative effect against unrestricted sociosexually, resulting in individuals with high level conscientiousness certainly choose to follow the existing norms because this type of individual will be very careful and concern with the future consequences. Thus, it can be believed that employees with high conscientiousness have no intention to engage in a workplace affair. This become the hypothesis 3 (H3) in this research which states: The employees' conscientiousness in Jabodetabek has a negative effect on their intention to engage in the workplace affair.

Furthermore, ccording to Doll \& Rosopa (2015), it states that there is a negative relationship between conscientiousness and the attitudes towards workplace romance. So, from the research results, it can also be believed that employees with high conscientiousness certainly has a negative attitude towards workplace affair because of their thoroughness, these employees prefer not to siding with a workplace affair. This leads to the hypothesis 5 (H5) that states: The conscientiousness of employees in Jabodetabek has a negative effect to their attitude towards the workplace affair.

\section{METHODS}

This research tries to test the model proposed by Doll \& Rosopa (2015) who study workplace romance. The study concluded that personal characteristic gives a significant contribution to the intention of employee's engagement in a workplace romance. Personal characteristics in that research include attitude, past behaviour and conscientiousness level.

Based on the research design of Malhotra (2010), this study is a conclusive research which is defined to test the hypothesis and analyze the effect of the research criteria in structured way, quantitative analysis, with a large and representative sample. In 
the data collection process, the method used is a single cross-sectional method, with data collection done one time within a certain period of the targeted population (Malhotra, 2010). Data in this study will be obtained from distributing questionnaires given in a form of questions and systematic statements, which followed by data processing. Sampling conducted using a nonprobability procedure sampling. Data was collected through surveys with convenience method. Respondents in this study were employees in the Jabodetabek area (Greater Jakarta) and have worked in a company/ organization for at least six months. In processing data, researchers use the Structural Equation Modeling (SEM) method through software Lisrel 8.51 (Jöreskog and Sörbom, 2006).

Research of Doll \& Rosopa (2015) specifically identified that conscientiousness and past behaviour directly affect the likelihood of employees to engage in workplace romance (H1 \& H3). Past behaviour affects engagement positively, while conscientiousness affects engagement negatively. Past behaviour and conscientiousness also give impact to employee's attitude (H4 \& H5), and in the end, the attitude will affect willingness to engage in workplace romance positively (H2) thus, in the model attitude plays as mediator. However, research of Doll \& Rosopa (2015) focused on engagement in a workplace romance, while engagement in workplace affair has not been explored yet. Therefore, the research model in this study is different from the study of Doll \& Rosopa (2015). In this study, there is a modification where the dependent variable is engagement in workplace affair rather than engagement in workplace romance as previously conducted by Doll \& Rosopa in 2015.

Workplace affair is defined as a relationship where one or both parties involved already engaged in marriage. A scenario is proposed to measure the willingness of engagement in workplace affair, which illustrated the affair relationship between two employees. The respondents must project the scenario into themselves and make the hypothetical game as if they were the employees who involved in the affair. Afterwards, the respondents need to answer the question in Likert rating scale 1-5 whether they are willing or unwilling to engage in the affair illustrated in the scenario. The scenario design aims to portray the affair based on a utilitarian motive, and the man is the one who is bound in a legal marriage.

In this study, attitude is defined as an evaluative judgement towards workplace romance. The attitude is measured using an instrument developed

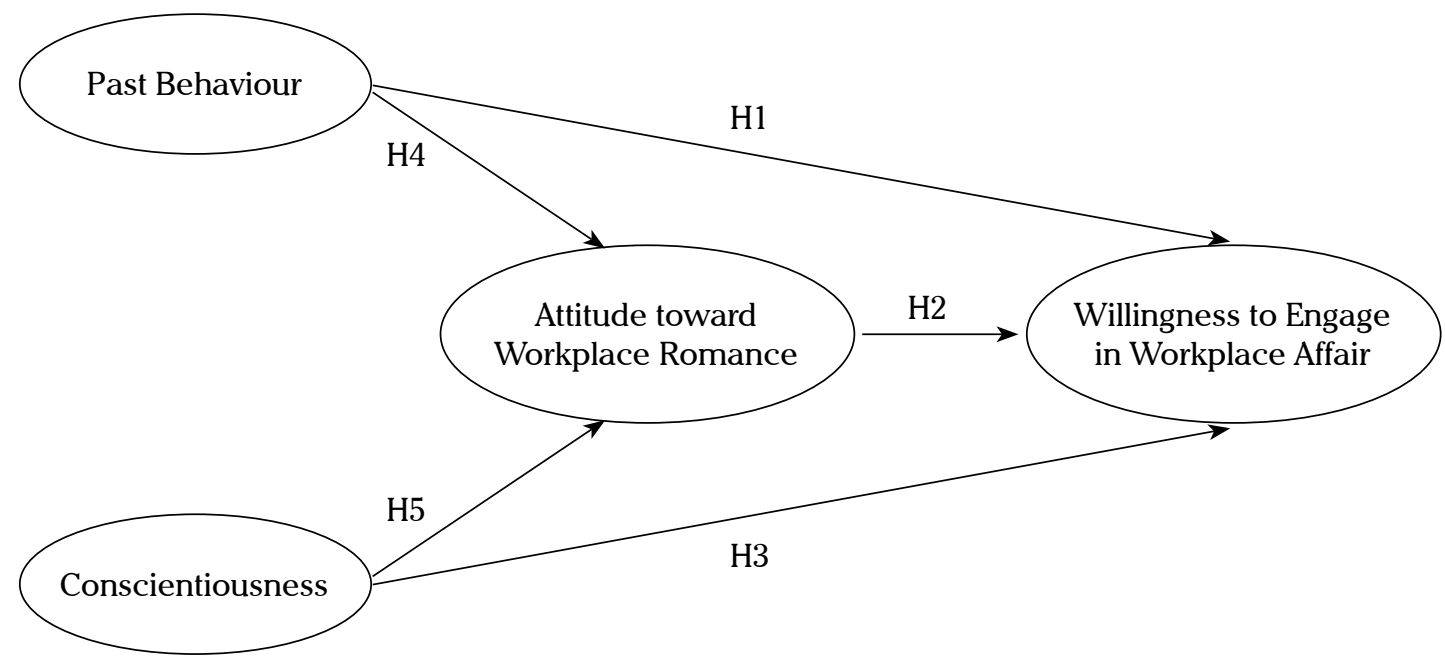

Figure 1. Research Model 
by Powell (1986) in Pierce (1998). It consists of eight items, and the respondents answer every question in Likert scale 1-5. Past Behaviour is defined as a person's experience in a workplace romance. This variable only highlights the experience of romance in general. The instrument does not explicitly measure the respondent's past behaviour in workplace affair since it is a sensitive question and not every respondent is willing to answer and admit past behaviour which has negative connotation such as an affair. Conscientiousness level is measured through persistence, self-control, and motivation that every respondent has.

\section{Variable Operationalization}

1. Variable Workplace Affair

This variable is tested via a scenario with the following questions included in the form of a rating. Workplace Affair Scenarios:

"A single female employee named Kimberly (not real name) was involved in a relationship with his married superior named David (not his real name). Kimberly's aim in this relationship is to reach faster career progression. Meanwhile, David, in this relationship is seeking more adventure, joy, and ego fullfilment. This relationship is kept in private. Still, rumors about this relationship spreadand become a topic of conversation in their workplace. This relationship creates the jealousy of other employees towards Kimberly who is considered to get more special treatment. This is also affected on David's image who was no longer seen as a respected boss".

This scenario is based on a survey conducted by Victoria Milan (2013), a site of affair findings, of 3,256 women, found that $38 \%$ of women said that having an affair with their boss is their first cheating experience. Besides, llicitEncounters.com (2017), an international dating site that surveyed 10,000 its users find that $40 \%$ of men have a hard time suppressing their egos as well as want to have it all. So that from each motive if put together be a utlitarian motive.

\section{Variable Attitude}

In this research, attitude is stated as an individual evaluative statement of the workplace affair. Attitude variable measured using a measuring instrument developed by Powell (1986) in Pierce (1998) which consists of eight statement items on a Likert scale of 1-5.

\section{Variable Past Behavior}

The role of past behavior has become a major topic in linking the attitude and behavior relationship, thus some studies consistently shows that past behavior is able to predict future behavior better than the determinants of behavior such as attitude or intention (Verplanken \& Orbell, 2003). Past Behavior in this research is the past behavior of individuals involved in workplace romance. In this variable, past behavior is only intended for behavior related to relationships limited to workplace romance, it does not go specifically as a workplace affair considering that not all individuals can admit their past behavior in negative connotation. Past behavior or prior engagement variables are questions about the frequency / number of respondents' involvement in their previous workplace romance.

\section{Variable Conscientiousness}

Conscientiousness symbolizes the individual's ability in organizing something, their persistence, self-control, and motivation in behaving in accordance with their end goal (Costa \& McCrae, 1990). In this study, conscientiousness is defined as thoroughness, persistence, self-control, and his motivation to act, or have the intention to engage in a workplace affair with a measurement indicator sourced from (Goldberg, 1999).

The respondents are workers from Jabodetabek Greater Area. It is a megapolitan area comprised of 5 cities; Jakarta, Bogor, Depok, Tangerang, Bekasi located in 3 provinces. The minimal respondent to test the hypotheses is 170 people following formula developed by Malhotra (2010). The formula requires the minimum number of respondents as the result of multiplication of indicators in 
questionnaire multiplied by five. The number of indicators in this study is 34 ; thus, the result of 34 multiplied by five is 170 . This formula follows the maximum likelihood method, which stated that the minimum sample size is between 100 to 500 to be able to be processed using the structural equation model or SEM (Wijanto, 2008). In the end, as many as 257 questionnaires are distributed, and 250 questionnaires are eligible to be further processed.

\section{RESULTS AND DISCUSSION}

\section{Result}

Descriptive analysis is conducted by computing the mean of respondents' answer for every variable. Measurement is using five scale Likert, which mean if the mean is closer to 5 , the variable is higher and vice versa.
Measurement model explains the association between observable variable or indicator with the latent variable. In this stage, variability test, reliability test, and goodness of fit model are performed. To measure the reliability of the model, it refers to the score of Composite Reliability (CR) and Variance Extracted (VE). The result of measurement model analysis is presented in table 2 .

After checking all the test of the measurement, the model meets the goodness of fit criteria. The next step is to analyse the structural model. In this step, when the variable already has good validity and reliability, the structural model is added to create a hybrid model. The purpose of this stage is to analyse the causal effect between variables to answer research hypotheses. In this step, there

Table 1. Descriptive Statistics

\begin{tabular}{|c|c|}
\hline Variable & Mean \\
\hline Willingness to Engage in Workplace Affair & 1.56 \\
\hline Attitude toward Workplace Romance & 3.07 \\
\hline Past Behavior of Workplace Romance & 1.85 \\
\hline Conscientiousness & 3.36 \\
\hline Gender & Percentage \\
\hline Male & $43 \%$ (107 respondents) \\
\hline Female & $57 \%$ (143 respondents) \\
\hline Marital Status & Percentage \\
\hline Married & $12 \%$ (30 respondents) \\
\hline Not Married & $86.8 \%$ (217 respondents) \\
\hline Do not answer & $1.2 \%$ (3 respondents) \\
\hline Working Location & Percentage \\
\hline West Jakarta & $11.6 \%$ (29 respondents) \\
\hline Central Jakarta & $25.2 \%$ (63 respondents) \\
\hline South Jakarta & $35.2 \%$ (88 respondents) \\
\hline East Jakarta & $6.4 \%$ (16 respondents) \\
\hline North Jakarta & $5.6 \%$ (14 respondents) \\
\hline Bekasi & $1.6 \%$ (4 respondents) \\
\hline Bogor & 0.4\% (1 respondents) \\
\hline Depok & 4.4\% (11 respondents) \\
\hline Tangerang & $9.6 \%$ (24 respondents) \\
\hline Age & Percentage \\
\hline $18-22$ & $35.6 \%$ (89 respondents) \\
\hline $23-31$ & $59.6 \%$ (149 respondents) \\
\hline $32-38$ & $2.8 \%$ (7 respondents) \\
\hline $39-45$ & $0.8 \%$ (2 respondents) \\
\hline$>45$ & $1.2 \%$ (3 respondents) \\
\hline
\end{tabular}


Table 2. Analysis of Goodness of Fit of Measurement Model

\begin{tabular}{|c|c|c|c|}
\hline $\begin{array}{c}\text { The goodness of Fit } \\
\text { Measurement }\end{array}$ & Acceptable Level of Fit & Measurement Result & Interpretation \\
\hline Chi-square & Smaller, better & $\begin{array}{c}(P=0,0) \\
150,82\end{array}$ & \\
\hline $\begin{array}{l}\text { Root Mean Square } \\
\text { Error of } \\
\text { Approximation } \\
\text { (RMSEA) }\end{array}$ & $\begin{array}{l}\text { RMSEA } \leq 0.08 \text { is good-fit } \\
\text { RMSEA } \leq 0.05 \text { is close-fit. }\end{array}$ & 0,076 & Good Fit \\
\hline $\begin{array}{l}\text { The goodness of fit } \\
\text { Index (GFI) }\end{array}$ & $\begin{aligned} \mathrm{GFI} & \geq 0.9 \text { is a good fit } \\
0.8 & \leq \mathrm{GFI} \leq 0.90 \text { is marginal fit. }\end{aligned}$ & 0,92 & Good Fit \\
\hline $\begin{array}{l}\text { Root Mean Square } \\
\text { Residual } \\
\text { (RMR) }\end{array}$ & Standardised RMR $\leq 0,05$ is good-fit. & 0,065 & Marginal Fit \\
\hline $\begin{array}{l}\text { Non-Formed Fit Index } \\
\text { (NNFI) }\end{array}$ & $\begin{array}{l}\text { NNFI } \geq 0.90 \text { is good-fit, } \\
0.80 \leq \text { NNFI }<0.90 \text { is marginal fit. }\end{array}$ & 0,92 & Good Fit \\
\hline Normed Fit Index (NFI) & $\begin{array}{l}\mathrm{NFI} \geq 0.90 \text { is good-fit } \\
0.80 \leq \mathrm{NFI}<0.90 \text { is marginal fit. }\end{array}$ & 0,91 & Good Fit \\
\hline $\begin{array}{l}\text { Adjusted Goodness of } \\
\text { Fit Index (AGFI) }\end{array}$ & $\begin{array}{l}\text { AGFI } \geq 0.90 \text { is good-fit } \\
0.8 \leq \mathrm{AGFI}<0.9 \text { is a marginal fit. }\end{array}$ & 0,87 & Marginal Fit \\
\hline Relative Fit Index (RFI) & $\begin{array}{l}\text { RFI } \geq 0.90 \text { is good-fit, } \\
0,80 \leq \mathrm{RFI}<0,90 \text { is marginal fit. }\end{array}$ & 0,88 & Marginal Fit \\
\hline $\begin{array}{l}\text { Incremental Fit Index } \\
\text { (IFI) }\end{array}$ & $\begin{array}{l}\text { IFI } \geq 0,90 \text { is good-fit, } \\
0,80 \leq \mathrm{RFI}<0,90 \text { is marginal fit. }\end{array}$ & 0,94 & Good Fit \\
\hline $\begin{array}{l}\text { Comparative Fit Index } \\
(\mathrm{CFI})\end{array}$ & $\begin{array}{l}\mathrm{CFI} \geq 0.90 \text { is good-fit, } \\
0.80 \leq \mathrm{CFI}<0.90 \text { is marginal fit. }\end{array}$ & 0,94 & Good Fit \\
\hline $\begin{array}{l}\text { Composite Reliability } \\
\text { (CR) }\end{array}$ & Minimal 0.6 & $\begin{array}{l}\text { Willingness to } \\
\text { Engage }=0,881 \\
\text { Attitude }=0,826 \\
\text { Past Behavior }=0,957 \\
\text { Conscientiousness }=0,774\end{array}$ & Reliable \\
\hline $\begin{array}{l}\text { Variance Extracted } \\
\text { (VE) }\end{array}$ & Minimal 0.4 & $\begin{array}{l}\text { Willingness to } \\
\text { Engage }=0,716 \\
\text { Attitude }=0,614 \\
\text { Past Behavior }=0,918 \\
\text { Conscientiousness }=0,411\end{array}$ & Reliable \\
\hline
\end{tabular}

are two processes to perform; t-value analysis and mediating analysis.

The findings show that not all the research hypotheses are accepted because of the unavailability of a causal connection between variables. Hypotheses 2 and 4 are accepted which stated that past behaviour of the employee concerning workplace romance would affect the attitude (H4) and the attitude towards workplace romance will positively affect the likelihood of employees to engage in workplace affair (H2). From the finding, it reveals that attitude plays as a mediating variable between past behaviour and engagement. It means past behaviour does not directly lead to workplace affair engagement if the employee has a negative attitude towards workplace romance. The past behaviour of an employee who engages in workplace romance will likely lead to engagement in workplace affair in the future if the attitude of the employee towards workplace romance is positive. Without the effect of attitude, past behaviour alone cannot predict the future behaviour of the employee. Therefore, attitude is full mediation between past behaviour and the likelihood of engagement of workplace 
affair or can be simplified as future behaviour. Future behaviour can be predicted by past behaviour through attitude as the mediator. The research findings are depicted in figure 2.

Hypothesis 1 (H1), which stated that past behaviour has a direct positive impact on the engagement of workplace affair is rejected. This hypothesis formulation refers to the argument of Trafimow \& Borrie (1999), who argued that past behaviour could predict the intention of a person to exercise similar action in the future. However, the findings of this study are not fully supported the proposition. Past behaviour of employee's engagement in workplace romance can impact the intention of the employee to engage in workplace affair or future behaviour indirectly. The attitude of the employee towards workplace romance is the condition that the past behaviour will lead to the manifestation of future behaviour. It means the previous behaviour will not affect the likelihood of similar behaviour in the future if the person's attitude towards that behaviour is not favourable. It emphasises the importance of attitude as the predictor of behaviour. Experience is not the perfect predictor of future behaviour since it is mediated by the attitude of a person has. This finding can be explained using Ajzen (1985) proposition in the theory of planned behaviour or TPB. TPB explains that the decision of a person to behave in a certain way is determined by the attitude of a person in evaluating that behaviour. It concludes that a worker will tend to engage in a workplace romance, or specifically in this study workplace affair if the worker has previous experience in having romance relationship at work or his/her past behaviour and it is followed by the positive attitude of the worker in evaluating the workplace romance itself. If the employee has experience concerning workplace romance, but the attitude of workplace romance is negative, the likelihood of employee will engage in future relationship of romance at work is lower. The mediating effect of attitude is perfect; thus, it fully mediates the relationship between past and future behaviour.
Hypothesis 3 and 5, which stated that conscientiousness would give a negative impact on the engagement of workplace affair directly and to attitude are rejected. It reveals that personality disposition does not give any impact on workplace romance attitude and engagement. Previously, the study proposed that conscientiousness personality will have a negative impact on workplace romance attitude and workplace affair engagement. If a person has a high score in conscientiousness, it will affect the attitude and the engagement negatively and vice versa. However, it reveals that conscientiousness does not give any impact on attitude and engagement. It implies neither person with a high score of conscientiousness nor low score of conscientiousness will determine the attitude and the likelihood of future engagement in workplace affair.

Further elaboration needs to conduct in explaining the reason behind the insignificant effect of personality determinant, especially conscientiousness personality, in predicting the attitude and behaviour of workers concerning workplace romance. However, the probable explanation behind this finding is due to the characteristic of the sample. Respondent of the study is coming from Jakarta, Bogor, Depok, Tangerang, and Bekasi or Jabodetabek; this is the megapolitan area where all workers in this location can be classified as urban workers.

\section{Discussion}

Following the theory of Ferdinand Tonnies (Marius, 2006), workers in an urban area is a part of the city's community or Gesellschaft. Gesselschaft community is characterised as pragmatic, which means when it comes to social relationship, the basis for them to form relationships is the utility. Urban workers usually have formal social relation, oriented to economic calculation, and tend to be more open. Urban workers can accept diverse ideas, perspectives, arguments, and conclusions. Urban workers also strongly associated as more achievement-oriented since in cities, competition 


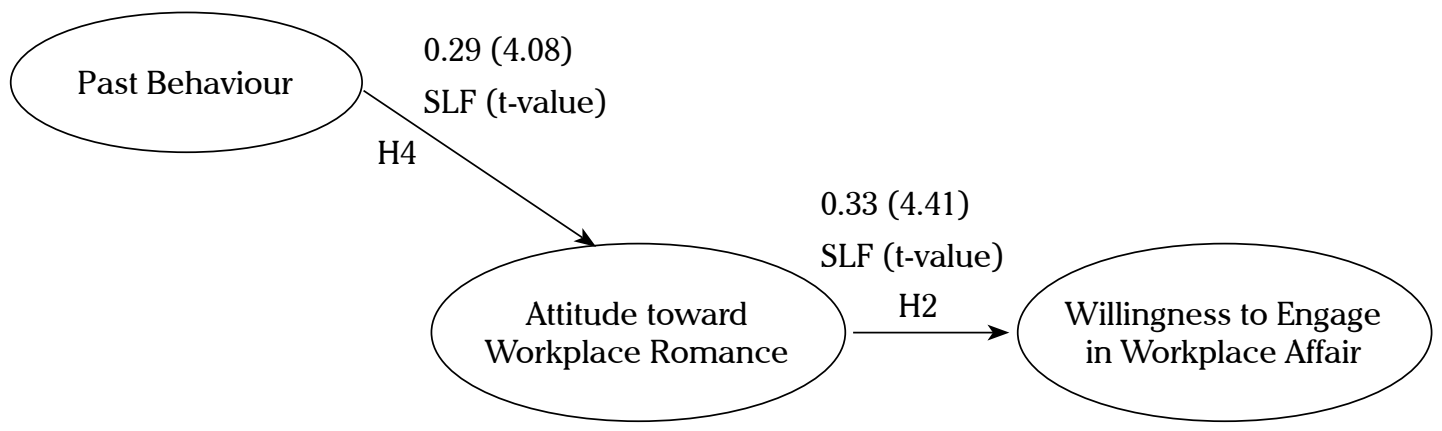

Figure 2. Research Finding

becomes an inseparable aspect of the community. The indication of people with a high score of conscientiousness is the willingness to compete and achieve a personal goal. From the means score, the level of conscientiousness of the respondent in this study is 3.36 in the 1-5 scale. It implies that the majority of the respondent is fit with the proposition that urban workers tend to be more conscientiousness because competition surrounds them daily.

It can explain why conscientiousness does not play any roles in determining attitude and engagement in workplace affair. People with high-level conscientiousness tend to ignore the things unrelated to their personal goal. Working in an urban area is competitive; thus, only people with high conscientiousness can adjust to the pace of cities faster. Since workplace romance may be perceived as unrelated to a personal goal, it conceived as a more private aspect of a person. It may lead to the impact that conscientiousness plays essential roles in determining attitude and behaviour of workers that boost the worker's achievement, but it does not play any roles in determining attitude and behaviour to the things considered as unimportant such as workplace romance. Workplace romance phenomenon is perceived as irrelevant in contributing to personal success, and as long as it does not disturb work performance and organisation, it can be neglected. The critical finding from this study is that past behaviour is more accurate in predicting attitude and future behaviour of the employee concerning workplace romance while personality determinant cannot be utilised as an aspect in predicting employee's attitude and their future behaviour. Besides, this study also reveals the result towards workplace affair, another new perspective beyond workplace romance, the dark side of workplace romance. However, past behaviour does not impact directly on engagement in workplace affair. Attitude mediates the relationship; thus, past behaviour cannot solely predict future behaviour without any effect from the attitude.

\section{MANAGERIAL IMPLICATION}

The study gives practical implication in preventing and mitigating workplace affair. Background checking is a crucial step in preventing workplace affair before the candidate joining the organisation. Analysing employee's track record primarily related to their past behaviour in workplace romance is very important to prevent workplace affair to occur in the future. This background checking can be a practical consideration for an organisation to accept or to reject prospective candidates; thus, it is not only considering the employee's competency but also employee's personal history which may give effect to the working behaviour in the future. Past behaviour in workplace romance also can be utilised as consideration for promotion and career development mainly if the employee engaged in unethical workplace romance such as an affair. The 
tendency of people to replicate similar behaviour will higher if they have previous experience of it. It means promotion and career development cannot solely root on working performance.

In this study, it is found that employees have a tendency to engage in a workplace romance, specifically workplace affair, when they have experience in a relationship at work (past behavior), followed by a positive attitude towards workplace romance phenomenon, both legally and non-legally in which we call as workplace affair. From the finding, researchers suggest several managerial implications for the organization or companies in addressing this phenomenon. First, background checking is necessary to be conducted especially in checking the track record of their employees' past behavior, whether they once engaged in a workplace romance or workplace affair and how was the effect of the relationship to the organization. This can be used as an ethical consideration for organizations or company, particularly in planning the promotions for middle-up management positions. The recruitment of the new hires also needs to get more attention in filtering the employees' historical background. This is important for organization or company to mitigate the unwanted events in the future by having employees with bad track record in workplace romance and/ or workplace affair.

Secondly, the socialisation of ethical conduct and corporate values is also essential, especially during the process of orientation before the new employee starts working and during the training and development process. The organisation must insist that workplace affair is unethical and unacceptable and try to internalise it as part of corporate values. Socialisation intensively is vital to shaping the attitude of the employee in evaluating and judging workplace affair. If the negative attitude towards workplace affair has been developed, the tendency of the employee to engage in workplace affair can be reduced even though perhaps the employee has experience about it, but it does not guarantee that similar behaviour will automatically manifest in the future since attitude plays as the mediator of the relationship between past and future behaviour of the employee.

\section{CONCLUSION}

Past behaviour in the workplace romance of workers in Jabodetabek gives positive impact to the employee's attitude. This finding strengthens the argument of Doll \& Rosopa (2015) which argued that there is a positive relationship between past behaviour and attitude. The attitude itself is a predictor of behaviour and mediator between past behaviour and future behaviour. However, personality disposition does not give any impact on attitude and engagement in workplace affair. Conscientiousness is insignificant in determining both attitude and engagement. Personality is not a fundamental aspect of predicting the future behaviour of people. It is experience and attitude that plays a significant role in anticipating the future behaviour of a person, especially in the context of a workplace affair.

This research is limited to covering respondents in the Jabodetabek area with most respondents are Jakarta employees. Different view may be felt by workers in other cities in Indonesia especially a small town who views the workplace affair phenomenon from different perspective due to different culture. 270 respondents in Jabodetabek, with total workers there are almost five million productive people in Jabodetabek, it is not that proportionally represents the views held by workers in Greater Jakarta. The questionnaire in this study also has limitations because it does not ask the respondent's past behavior regarding the workplace affair directly. Questions about the past behavior of employees in a workplace affair that connotes negatively allows respondents to choose not to express it bluntly, so that, in the variable past behavior the researcher directs the respondent to answer employees past behavior in workplace romance. 
This study has several caveats; thus, it needs to be anticipated in the future if a similar study to be conducted. In this study, when it discussed personality determinant, it only refers to the conscientiousness. In the Big Five Model, personality dimensions consist of five factors, not just one factor. As the consequences, when discussing the effect of personality on the engagement of workplace affair, the future study must include the rest of personality traits; extraversion, openness to experience, agreeableness, and neuroticism. This study also does not focus on exploring the phenomenon in a specific industry and include all workers from various sectors. It may lead to a vague conclusion since every industry usually has its characteristic, which perhaps contributes to the different research result. Focusing on one industrial sector may be necessary for understanding the phenomenon deeper and considering the uniqueness of every sector.

REFEREN C ES

International Research Journal of Business Studies (IRJBS)

Vol.x, No.x, Month 201x, pp. xx $\sim \mathrm{xx}$

ISSN: 2089-6271 | E-ISSN: 2338-4565 |www.irjbs.com

Abzug, R. (2016). Extramarital affairs as occupational hazard: A structural, ethical (cultural) model of opportunity. Sexualities, 19(2), 25-45. doi:10.1177/1363460715583586

Ajzen, I. (1985). From Intentions to Actions: A Theory of Planned Behavior. In Action control, Berlin, Heidelberg: Springer. doi: 10.1007/978-3-642-69746-3_2

Ajzen, I. and Fishbein, M. (1980). Understanding Attitudes and Predicting Social Behavior. Englewood Cliffs. New Jersey: Prentice-Hall.

Ali, I. (2018). Personality traits, individual innovativeness and satisfaction with life. Journal of Innovation \& Knowledge, 7(3), 1-11. doi: 10.1016/J.JIK.2017.11.002

Ariani, M. G., Ebrahimi, S. S., \& Saeedi, A. (2011). Managing workplace romance; a headache for human resource leaders. 3rd International Conference on Advanced Management Science, 19, 99-103.

Arora, R., \& Rangnekar, S. (2016). Linking the Big Five personality factors and career commitment dimensions. Journal of Management Development, 35(9), 1134-1148. doi: 10.1108/JMD-10-2015-0142

Banker, J. E., Kaestle, C. E., \& Allen, K. R. (2010). Dating is hard work: A narrative approach to understanding sexual and romantic relationships in young adulthood. Contemporary Family Therapy, 32(2), 173-191. doi: 10.1007/s10591-0099111-9

BBC Indonesia. (2017). Apa yang Akan Terjadi Jika Hubungan Cinta di Tempat Kerja Berakhir Buruk? Retrieved from BBC Indonesia website: http://www.bbc.com/indonesia/vert_cap/2016/04/160407_vert_cap_percintaan_kantor

Biggs, D., Matthewman, L., \& Fultz, C. (2012). Romantic relationships in organisational settings. Gender in Management: An International Journal, 27(4), 271-285. doi: 10.1108/17542411211244803

Career Intelligence. (2018). Romance in The Workplace: The Good, The Bad and The Ugly. Retrieved from Career Intelligence website: http:/career-intelligence.com/romance-in-the-workplace-the-good-the-bad/

Costa, P. T., \& McCrae, R. R. (1990). Personality Disorders and The Five-Factor Model of Personality. Journal of Personality Disorders, 4(4), 362-371. doi: 10.1521/pedi.1990.4.4.362

Doll, J. L., \& Rosopa, P. J. (2015). Workplace romances: examining attitudes, experience, conscientiousness, and policies. Journal of Managerial Psychology, 30(4), 439-453. doi: 10.1108/JMP-11-2012-0368

Fan, C. S., \& Lui, H. K. (2004). Extramarital affairs, marital satisfaction, and divorce: Evidence from Hong Kong. Contemporary Economic Policy, 22(4), 442-452. doi: 10.1093/cep/byh033

Foong, S.-Y., \& Khoo, C.-H. (2015). Attitude, learning environment and current knowledge enhancement of accounting students in Malaysia. Journal of Accounting in Emerging Economies, 5(2), 202-221. doi: 10.1108/JAEE-07-2012-0030 
Jahan, Y., Chowdhury, A. S., Rahman, S. M. A., Chowdhury, S., Khair, Z., Huq, K. A. T. M. E. \& Rahman, M. M. (2017). Factors involving extramarital affairs among married adults in Bangladesh. International Journal of Community Medicine and Public Health, 4(5), 13-79. doi: 10.18203/2394-6040.ijcmph20171506

Karl, K. A., \& Sutton, C. L. (2000). An examination of the perceived fairness of workplace romance policies. Journal of Business and Psychology, 14(3), 429- 442. doi: 10.1023/a:1022928216431

Kolesnikova, J., \& Analoui, F. (2012). Managing human resource romance at work: towards a "considerate" approach. Journal of Management Development, 32(1), 36-56. doi: 10.1108/02621711311286991

Mainiero, L.A. (1989). Office romance: Love, power, and sex in the workplace. New York: Rawson Associates.

Malhotra. (2010). Marketing Research: An Applied Orientation (6th Edition). New York: Prentice-Hall.

Marius, J. A. (2006). Perubahan Sosial. Jurnal Penyuluhan, 2(2), 125-132. doi: 10.1007/s13398-014-0173-7.2

Ouellette, J. A., \& Wood, W. (1998). Habit and intention in everyday life: The multiple processes by which past behavior predicts future behavior. Psychological Bulletin, 124(1), 54-74. doi: 10.1037/0033-2909.124.1.54

Pierce, C. A. (1998). Factors associated with participating in a romantic relationship in a work environment. Journal of Applied Social Psychology, 28(18), 1712-1730. doi: 10.1111/j.1559-1816.1998.tb01342.x

Pierce, C. A., \& Aguinis, H. (2001). A Framework for Investigating the Link between Workplace Romance and Sexual Harassment. Group and Organization Management, 26(2), 206-229. doi: 10.1177/1059601101262005

Pierce, C. A., Karl, K. A., \& Brey, E. T. (2012). Role of workplace romance policies and procedures on job pursuit intentions. Journal of Managerial Psychology, 27(3), 237-263. doi: 10.1108/02683941211205808

Pizam, A. (2016). Workplace romance in the hospitality industry. International Journal of Hospitality Management, 56, $136-137$. doi: 10.1016/j.ijhm.2016.06.001

LaBier, D. (2010). Having an Affair? There Are Six Kinds Different Things. Retrieved from Psychology Today website https:// www.psychologytoday.com

Quinn, R. (1977). Coping with cupid: The formation, impact, and management of romantic relationships in organisations. Administrative Science Quarterly, 22, 30-45.

Shuck, B., Owen, J., Manthos, M., Quirk, K., \& Rhoades, G. (2016). Co-workers with benefits. Journal of Management Development, 35(3), 382-393. doi: 10.1108/JMD-02-2015-0014

The Economist. (2005). The End of The Office Affair? Retrieved from The Economist website: https://www.economist.com/ node/3743745

Trafimow, D., \& Borrie, W. T. (1999). Influencing future behaviour by priming past behavior: A test in the context of petrified forest national park. Leisure Sciences, 21(1), 31-42. doi: 10.1080/014904099273273

Wall Street Journal. (2007). Red Cross Ousts CEO Everson. Retrieved from Wall Street Journal website https://www.wsj.com/ articles/SB119619004451105488

Wheatcroft, J. (2016). Love is all around us in the workplace. Human Resource Management International Digest, 24(6), 21-23. doi: 10.1108/HRMID-05-2016-0079

Wijanto, S. H. (2008). Structural Equation Modeling dengan LISREL 8.8: Konsep dan tutorial. Yogyakarta: Graha Ilmu. 